\title{
Glucocorticoid-induced insulin resistance of protein synthesis is independent of the rapamycin-sensitive pathways in rat skeletal muscle
}

\author{
D Dardevet, C Sornet and J Grizard
}

Unité d'Etude du Métabolisme Azoté, Institut National de la Recherche Agronomique, 63122 Ceyrat, France

(Requests for offprints should be addressed to D Dardevet)

\begin{abstract}
This study was designed to evaluate the role of p70 S6 kinase $\left(\mathrm{p} 70^{\mathrm{S} 6 \mathrm{~K}}\right)$, p90 S6 kinase $\left(\mathrm{p} 90^{\mathrm{RSK}}\right)$ and mitogenactivated protein (MAP) kinase pathways in the insulin resistance of muscle protein synthesis observed during glucocorticoid treatment. Dexamethasone treatment decreased the effect of insulin on protein synthesis $(-35 \cdot 2 \%)$ in epitrochlearis muscle incubated in vitro. This resistance is associated with a total blockage of the stimulation of $\mathrm{p} 70^{\mathrm{S} 6 \mathrm{~K}}$ by insulin without any significant decrease in the amount of the kinase. However, the effect of rapamycin (inhibitor of several intracellular pathways including $\mathrm{p} 70^{\mathrm{S} 6 \mathrm{~K}}$ pathways) on muscle protein synthesis was not modified by dexamethasone in rat muscles. This
\end{abstract}

suggested that 'rapamycin-sensitive pathways' associated with the insulin stimulation of protein synthesis were not altered by glucocorticoids and thus are not responsible for the insulin resistance observed. As incubation of muscles with a MAP kinase inhibitor (PD98059) did not modify the stimulation of protein synthesis by insulin and as glucocorticoids did not alter the effect of insulin on $\mathrm{p} 90^{\mathrm{RSK}}$ activity, our results provide evidence that glucocorticoidinduced alterations in muscle protein synthesis regulation by insulin do not involve factors or kinases that are dependent on MAP kinase and/or $\mathrm{p} 90^{\mathrm{RSK}}$.

Journal of Endocrinology (1999) 162, 77-85

\section{Introduction}

Circulating levels of glucocorticoids are elevated in Cushing's syndrome, infections, stress and various traumatic conditions and clinical treatments (Dujovne \& Azarnoff 1975, Vaughan et al. 1982, Legaspi et al. 1985, Bondy 1985, Tessitore et al. 1993). The association of glucocorticoid excess and muscle atrophy is now well established, and the mechanisms underlying muscle wasting consistently involve inhibition of skeletal muscle protein synthesis and/or increased proteolysis (Tomas et al. 1979, Rannels \& Jefferson 1980, McGrath \& Goldspink 1982, Odedra et al. 1983, Kayali et al. 1987). However, glucocorticoid-induced muscle atrophy may result from both the steroid effect per se and/or modification of anabolic hormone action on protein metabolism (i.e. insulin). Indeed, steroids are also known to be potent diabetogenic agents resulting from both hepatic and peripheral resistance to the action of insulin (Amatruda et al. 1985). It is well known that the actions of insulin on muscle glucose uptake (Weinstein et al. 1995), glycogen synthesis (Leighton et al.1987), protein synthesis (Southorn et al. 1990, Dardevet et al. 1998) and proteolysis (Louard et al. 1994, Dardevet et al. 1998) are altered after glucocorticoid treatment.
Cellular responses to insulin involve interaction of the hormone with its receptor and subsequent activation of intracellular signalling pathways. One of the earliest postreceptor events is phosphorylation of the insulin receptor substrate-1 (IRS-1) on tyrosine residues which in turn acts as a 'docking protein' to activate a number of different proteins, including phosphatidylinositol 3 kinase (PI3 kinase) and growth factor receptor-binding protein-2 (see Myers \& White (1993) and Denton \& Tavaré (1995) for reviews). The latter protein is thought to be linked to the activation of Ras, which subsequently activates the mitogen-activated protein (MAP) kinase pathways. PI3 kinase activation represents a general mechanism in muscle insulin signalling toward glucose metabolism (Okada et al. 1994, Cheatham et al. 1994, Yeh et al. 1995), protein synthesis (Dardevet et al. 1996, Thompson \& Palmer 1998) or proteolysis (Dardevet et al. 1996, Thompson \& Palmer 1998). The downstream events linked to PI3 kinase remain unclear but its activation is required for insulin stimulation of the p70 S6 kinase $\left(\mathrm{p} 70^{\mathrm{S} 6 \mathrm{~K}}\right)$ in skeletal muscle (Dardevet et al. 1996) and various cells (Cheatham et al. 1994, Cross et al.1994, Welsh et al. 1994). Interestingly, blunting the activation of $\mathrm{p} 70^{\mathrm{S} 6 \mathrm{~K}}$ with rapamycin impaired the stimulatory effect of insulin on protein synthesis in rat skeletal muscle 
(Dardevet et al. 1996) as well as in C2C12 myoblasts (Palmer et al. 1997) suggesting involvement of this kinase in the regulation of muscle protein synthesis by insulin.

The mechanism by which steroids alter insulin action on skeletal muscle protein synthesis remains unclear. Indeed, the first cellular events involved in the action of insulin, i.e. a change in insulin receptor number (Block \& Buse 1989, Giorgino et al. 1993, Saad et al. 1993), insulin receptor autophosphorylation (Block \& Buse 1989, Giorgino et al. 1993, Saad et al. 1993) and tyrosine phosphorylation of IRS-1 (Giorgino et al. 1993, Saad et al. 1993) are not modified by glucocorticoid treatment. Up to now, the only significant effect of glucocorticoids was a decrease in the association/activation of PI3 kinase with IRS-1 in response to insulin (Giorgino et al. 1993, Saad et al. 1993). However, it is not known if such an alteration modifies activation of the $\mathrm{p} 70^{\mathrm{S} 6 \mathrm{~K}}$ pathways or MAP kinase pathways by insulin. In an attempt to understand the origin of the insulin resistance of muscle protein synthesis after glucocorticoid treatment, we examined in the present study the action of dexamethasone (DEX) on the activity of selected intracellular protein kinases such as $\mathrm{p} 70^{\mathrm{S} 6 \mathrm{~K}}$ (rapamycin-sensitive pathway), p90 RSK and MAP kinases (rapamycin-insensitive pathway) in rat epitrochlearis muscle in vitro.

\section{Materials and Methods}

\section{Animals}

Young (4-5-week-old) male Sprague-Dawley rats were purchased from Iffa-Credo (L'Arbresle, France) and housed under controlled environmental conditions (temperature, $22{ }^{\circ} \mathrm{C} ; 12 \mathrm{~h}$ dark period starting at $1800 \mathrm{~h}$ ). They were given free access to commercial laboratory chow and water before the experiments were performed. Rats were randomly divided into a control and a DEX-treated group. DEX (a synthetic glucocorticoid analogue that does not bind to plasma binding proteins) was given daily (at $0900 \mathrm{~h}$ ) via the drinking water. DEX concentration was adjusted every day on the basis of drinking water intake the day before. Animals received $2 \cdot 19 \pm 0 \cdot 1 \mathrm{mg} / \mathrm{kg}$ per day for 4 days. As DEX was reported to decrease food intake, the control group was pair-fed to the DEX-treated group. Food intake was maintained at similar levels in the two groups during the DEX treatment as shown in Table 1. Thus differences between pair-fed and treated groups do not originate from different food intakes. DEX induced a progressive weight loss of $20 \%$ over the treatment period and the pair-fed animals stopped growing (Table 1). Animals were anaesthetized with sodium pentobarbital $(6.0 \mathrm{mg} / 100 \mathrm{~g}$ body weight $)$ after an overnight fast. Epitrochlearis muscles were dissected intact for incubation (see below). Separate animal protocols were performed to examine the effects of the inhibitors tested and to assess kinase activities (16 animals per groups).
Table 1 Body weight and food intake of pair-fed and DEX-treated rats

\begin{tabular}{|c|c|c|c|c|}
\hline \multirow[t]{2}{*}{ Day } & \multicolumn{2}{|l|}{ Pair-fed } & \multicolumn{2}{|l|}{ DEX-treated } \\
\hline & Weight (g) & $\begin{array}{l}\text { Food } \\
\text { intake }(\mathrm{g})\end{array}$ & Weight (g) & $\begin{array}{l}\text { Food } \\
\text { intake }(\mathrm{g})\end{array}$ \\
\hline 0 & $130 \cdot 8 \pm 1 \cdot 42$ & $15 \cdot 0$ & $130 \cdot 4 \pm 1 \cdot 51$ & $14 \cdot 7 \pm 0 \cdot 17$ \\
\hline 1 & $137 \cdot 4 \pm 1 \cdot 37$ & $9 \cdot 0$ & $128 \cdot 4 \pm 1 \cdot 79$ & $8 \cdot 8 \pm 0 \cdot 13$ \\
\hline 2 & $137 \cdot 0 \pm 1 \cdot 14$ & $9 \cdot 0$ & $120 \cdot 0 \pm 1 \cdot 58$ & $8 \cdot 5 \pm 0 \cdot 34$ \\
\hline 3 & $137 \cdot 4 \pm 1 \cdot 09$ & $9 \cdot 0$ & $114 \cdot 6 \pm 1 \cdot 58$ & $8 \cdot 8 \pm 0 \cdot 12$ \\
\hline 4 & $132 \cdot 5 \pm 0.97$ & $4 \cdot 0$ & $104 \cdot 3 \pm 1 \cdot 57$ & $4 \cdot 0$ \\
\hline
\end{tabular}

\section{Effect of rapamycin and PD98059 on insulin-stimulated protein synthesis}

The effect of the inhibitors was assessed by preincubating epitrochlearis muscle for $30 \mathrm{~min}$ in Krebs/Henseleit buffer ( $\mathrm{NaCl} 120 \mathrm{mM}, \mathrm{KCl} 4.8 \mathrm{mM}, \mathrm{NaHCO}_{3} 25 \mathrm{mM}, \mathrm{CaCl}_{2}$ $2.5 \mathrm{mM}, \mathrm{KH}_{2} \mathrm{PO}_{4} 1.2 \mathrm{mM}$ and $\mathrm{MgSO}_{4} 1.2 \mathrm{mM}$; $\mathrm{pH} 7 \cdot 4$ ) supplemented with $5 \mathrm{mM}$ Hepes, $5 \mathrm{mM}$ glucose, $0.17 \mathrm{mM}$ leucine, $0.20 \mathrm{mM}$ valine, $0.10 \mathrm{mM}$ isoleucine and $0 \cdot 1 \%$ BSA (99\% fatty acid free) and saturated with $95 \% \mathrm{O}_{2} / 5 \% \mathrm{CO}_{2}$ gas mixture in the presence or absence of $200 \mathrm{nM}$ rapamycin or $20 \mu \mathrm{M}$ PD98059. Muscles were then transferred to fresh medium of the same composition supplemented with $0.5 \mathrm{mM} \quad \mathrm{L}-\left[{ }^{14} \mathrm{C}\right]$ phenylalanine $(0 \cdot 15 \mu \mathrm{Ci} / \mathrm{ml})$ with or without $30 \mathrm{nM}$ insulin and incubated for an additional $90 \mathrm{~min}$ period. At the end of the incubation, muscles were blotted and homogenized in $10 \%$ trichloroacetic acid (TCA). Samples were centrifuged at $10000 \mathrm{~g}$ for $10 \mathrm{~min}$ at $4{ }^{\circ} \mathrm{C}$ and TCA-insoluble material was washed three times with $10 \%$ TCA. The resultant pellet was solubilized in $1 \mathrm{M} \mathrm{NaOH}$ at $37^{\circ} \mathrm{C}$ for determination of protein and radioactivity incorporated into muscle protein. Tissue protein mass was determined using the bicinchoninic acid procedure (BCA; Pierce Chemical Co., Rockford, IL, USA), and protein-bound radioactivity was measured using scintillation counting. Protein synthesis was calculated by dividing the protein-bound radioactivity by the specific radioactivity of the phenylalanine in the incubation medium. It was expressed as nmol phenylalanine incorporated/per mg protein per $90 \mathrm{~min}$.

\section{Assessment of $p 70^{S 6 K}$ and $p 90^{R S K}$ activities}

Epitrochlearis muscles were preincubated for $30 \mathrm{~min}$ in Krebs/Henseleit buffer supplemented with $5 \mathrm{mM}$ Hepes, $5 \mathrm{mM}$ glucose, $0.17 \mathrm{mM}$ leucine, $0.20 \mathrm{mM}$ valine, $0 \cdot 10 \mathrm{mM}$ isoleucine and $0 \cdot 1 \%$ BSA ( $99 \%$ fatty acid free) and saturated with $95 \% \mathrm{O}_{2} / 5 \% \mathrm{CO}_{2}$ gas mixture. Insulin $(30 \mathrm{nM})$ was then added to the medium and muscles were incubated for $20 \mathrm{~min}$ in the presence of the hormone. Muscles were homogenized in ice-cold extraction buffer $(50 \mathrm{mM}$ Tris/acetate, $50 \mathrm{mM} \mathrm{NaF}, 2.5 \mathrm{mM}$ EDTA, $1 \mathrm{mM}$ EGTA, $5 \mathrm{mM}$ sodium pyrophosphate, $5 \mathrm{mM}$ 
$\beta$-glycerophosphate, $1 \mathrm{mM} \mathrm{Na}_{3} \mathrm{VO}_{4}, 2 \mathrm{mM}$ dithiothreitol, $1 \mathrm{mM}$ benzamidine, $4 \mu \mathrm{g} / \mathrm{ml}$ leupeptin, $0.5 \%$ Triton $\mathrm{X}-100, \mathrm{pH} 7 \cdot 2$ ) and centrifuged at $10000 \mathrm{~g}$ for $10 \mathrm{~min}$ at $4{ }^{\circ} \mathrm{C}$.

The activity of $\mathrm{p} 70^{\mathrm{S} 6 \mathrm{~K}}$ was assessed by an immune complex kinase assay. Normalized amounts of muscle protein $(100 \mu \mathrm{g})$ were incubated for $4 \mathrm{~h}$ at $4{ }^{\circ} \mathrm{C}$ with $3 \mu \mathrm{l}$ p $70^{\mathrm{S} 6 \mathrm{~K}}$ antibodies preabsorbed to Protein $\mathrm{A} /$ agarose beads. The immune complexes were washed three times with S6 kinase assay buffer (25 mM Mops, $15 \mathrm{mM} \mathrm{MgCl}, 1 \mathrm{mM}$ dithiothreitol, $0 \cdot 1 \% \mathrm{BSA} ; \mathrm{pH} 7 \cdot 2$ ). The beads were then resuspended in $50 \mu \mathrm{l}$ S6 kinase assay buffer containing $0 \cdot 1 \mathrm{mM}$ S6 peptide RRRLSSLRA, $2 \mu \mathrm{M}$ peptide inhibitor of cAMP-dependent protein kinase and $100 \mathrm{mM}$ ATP (specific activity 3000 d.p.m./pmol). After a 60 min incubation at $30^{\circ} \mathrm{C}$, the phosphorylation reaction was stopped with $10 \mu \mathrm{l} 50 \mathrm{mM}$ unlabelled ATP. The reaction mixture was spotted on to Whatman P-81 phosphocellulose filter paper squares, which, after three washes in $75 \mathrm{mM}$ phosphoric acid, were counted in a $\beta$-scintillation counter. Pilot experiments showed that ${ }^{32} \mathrm{P}$ incorporation into S6 substrate was linear for at least $60 \mathrm{~min}$ and proportional to the amount of protein used (100-200 $\mu \mathrm{g})$.

The activity of $\mathrm{p} 90^{\mathrm{RSK}}$ was also assessed by an immune complex kinase assay as described for the $\mathrm{p} 70^{\mathrm{S} 6 \mathrm{~K}}$. Normalized amounts of muscle protein $(50 \mu \mathrm{g})$ were immunoprecipitated and then allowed to phosphorylate. After a 20 min incubation at $30^{\circ} \mathrm{C}$, the phosphorylation reaction was stopped, and radioactivity incorporated into the substrate was counted. Pilot experiments showed that ${ }^{32} \mathrm{P}$ incorporation into S6 substrate was linear for at least $40 \mathrm{~min}$ and proportional to the amount of protein used (50-100 $\mu \mathrm{g})$.

\section{Western blotting}

Aliquots of tissue supernatant ( $20 \mu \mathrm{g}$ protein) were analysed by SDS/PAGE ( $7 \cdot 5 \%$ polyacrylamide gel) under reducing conditions. Proteins were then transferred on to nylon membranes (Millipore Corp., Bedford, MA, USA) and subsequently blocked in TBS $(20 \mathrm{mM}$ Tris, $500 \mathrm{mM} \mathrm{NaCl}$, $\mathrm{pH} 7 \cdot 5$ ) supplemented with $5 \%$ non-fat powdered milk. Membranes were then exposed to a polyclonal antibody that specifically recognizes $\mathrm{p} 70^{\mathrm{S} 6 \mathrm{~K}}$ (SC-230; Santa Cruz Biotechnology, Santa Cruz, CA, USA) or p90 ${ }^{\text {RSK }}$ (SC-231; Santa Cruz Biotechnology) for $16 \mathrm{~h}$ at $4{ }^{\circ} \mathrm{C}$. After three washes in TBS with $0.05 \%$ Tween 20 supplemented with $1 \%$ milk, membranes were incubated for $45 \mathrm{~min}$ in the same buffer with a goat anti-rabbit antibody conjugated with horseradish peroxidase and developed using the enhanced chemoluminescence (ECL) detection system (Amersham) according to the manufacturer's directions.

\section{Statistical analysis}

Data are expressed as the means \pm s.E.M. Statistical evaluation of the data was performed using Student's $t$-test.
Differences among means were considered significant when $P<0 \cdot 05$.

\section{Results}

Effect of DEX on insulin-stimulated muscle protein synthesis

Glucocorticoid treatment induced skeletal muscle protein wasting in both epitrochlearis muscle $(22.9 \pm 1.2$ vs $16.7 \pm 0.6 \mathrm{mg}$ in pair-fed and treated rats respectively) and gastrocnemius muscle (774 \pm 3 vs $542 \pm 2 \mathrm{mg}$ in pair-fed and treated rats respectively). In pair-fed animals, muscle protein synthesis was significantly stimulated $(P<0 \cdot 05)$ by insulin $(0.248 \pm 0.0057$ vs $0.489 \pm 0.026$ nmol phenylalanine/mg protein per $90 \mathrm{~min}$ without and with insulin respectively). Food restriction did not significantly modify the effect of insulin on epitrochlearis protein synthesis when compared with a control ad libitum group $(0.295 \pm 0.023$ vs $0.485 \pm 0.048 \mathrm{nmol}$ phenylalanine $/ \mathrm{mg}$ protein per $90 \mathrm{~min}$ without and with insulin respectively). The basal rate of protein synthesis was significantly decreased in epitrochlearis muscle from rats treated with DEX $(0 \cdot 171 \pm 0 \cdot 0056 \mathrm{nmol}$ phenylalanine $/ \mathrm{mg}$ protein per $90 \mathrm{~min} ; P<0 \cdot 05$ vs untreated rats) (Fig. 1). Insulin was still able to stimulate protein synthesis $(0.327 \pm 0.013 \mathrm{nmol}$ phenylalanine $/ \mathrm{mg}$ protein per $90 \mathrm{~min} ; P<0.05$ vs basal) but to a lesser extent than in pair-fed controls (Fig. 1). Indeed, the incremental increase in protein synthesis above basal due to the effect of insulin was significantly decreased by $35.2 \% \quad(P<0.05)$ when animals were treated with DEX $(0 \cdot 241 \pm 0 \cdot 010$ vs $0 \cdot 156 \pm 0.005 \mathrm{nmol}$ phenylalanine $/ \mathrm{mg}$ protein per $90 \mathrm{~min}$ for pair-fed and DEX-treated rats respectively).

\section{Effect of PD98059 on insulin-stimulated protein synthesis}

Addition of PD98059 (an inhibitor of MAP kinase pathway) to the incubation medium did not modify the rate of basal muscle protein synthesis $(0 \cdot 248 \pm 0.006$ vs $0 \cdot 243 \pm 0 \cdot 010005 \mathrm{nmol}$ phenylalanine/mg protein per 90 min without or with the inhibitor respectively) nor the stimulatory effect of insulin in both pair-fed and Dextreated rats (Fig. 1). This result shows that the MAP kinase pathway is not involved in the acute regulation of muscle protein synthesis by insulin and thus could not be responsible for the defective hormone action under steroid treatment. To check the efficiency of the inhibitor, we assessed, in a side experiment, insulin-stimulated glucose transport. PD98059, at the concentration used above, completely inhibited the effect of the hormone on muscle deoxyglucose (1.859 \pm 0.179 and $3 \cdot 121 \pm 0 \cdot 297 \mathrm{nmol}$ deoxyglucose/mg muscle per $15 \mathrm{~min}$ without and with insulin in the absence of PD98059; $1.661 \pm 0.107$ and $2 \cdot 108 \pm 0 \cdot 273 \mathrm{nmol}$ deoxyglucose $/ \mathrm{mg}$ muscle per $15 \mathrm{~min}$ without and with insulin in the presence of PD98059). 


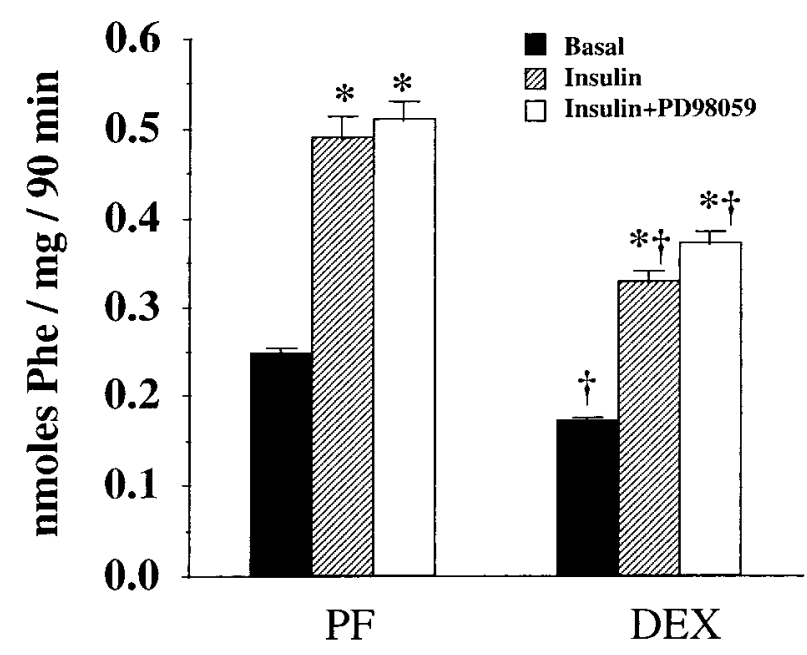

Figure 1 Effect of PD98059 on muscle protein synthesis. Epitrochlearis muscles from pair-fed (PF) and DEX-treated (DEX) rats were preincubated for $1 \mathrm{~h}$ in Krebs/Henseleit buffer supplemented with $5 \mathrm{mM}$ Hepes, $5 \mathrm{mM}$ glucose, $0.17 \mathrm{mM}$ leucine, $0 \cdot 2 \mathrm{mM}$ valine, $0 \cdot 1 \mathrm{mM}$ isoleucine and $0 \cdot 1 \% \mathrm{BSA}$ and saturated with $95 \% \mathrm{O}_{2} / 5 \% \mathrm{CO}_{2}$ gas mixture in the presence or absence of $20 \mu \mathrm{M}$ PD98059. Muscles were then transfered to fresh medium of the same composition supplemented with $0.5 \mathrm{mM} \mathrm{L}-\left[{ }^{14} \mathrm{C}\right]$ phenylalanine $(0 \cdot 15 \mu \mathrm{Ci} / \mathrm{ml})$ with or without $30 \mathrm{nM}$ insulin and incubated for an additional 90 min period. Muscles were blotted and homogenized in 10\% TCA. The resultant pellet was solubilized in $1 \mathrm{M} \mathrm{NaOH}$ at $37{ }^{\circ} \mathrm{C}$ for determination of muscle protein content and radioactivity incorporated into muscle proteins. Protein synthesis was expressed as nmol phenylalanine incorporated $/ \mathrm{mg}$ protein per $90 \mathrm{~min}$. Data are means \pm S.E. for six to eight individual muscles. ${ }^{\star}$ Significantly different from basal value $(P<0.05)$; †significantly different from the pair-fed value $(P<0 \cdot 05)$.

Effect of DEX on muscle insulin-stimulated $p 90^{R S K}$ and p $70^{\text {s6K }}$ activities

Insulin stimulated the activity of $\mathrm{p} 90^{\mathrm{RSK}}$ in epitrochlearis muscle from pair-fed rats $(3.01 \pm 0.170$ vs $2.07 \pm$ $0 \cdot 256 \mathrm{pmol}$ ATP $/ 50 \mu \mathrm{g}$ per $20 \mathrm{~min}$ with and without insulin respectively; $P<0 \cdot 05)($ Fig. 2). Treatment with DEX modified neither the basal activity of $\mathrm{p} 90^{\mathrm{RSK}}$ nor its stimulation by insulin $(2 \cdot 04 \pm 0 \cdot 165$ vs $3 \cdot 23 \pm 0 \cdot 181 \mathrm{pmol}$ $\mathrm{ATP} / 50 \mu \mathrm{g}$ per $20 \mathrm{~min}$ with and without insulin respectively; $P<0 \cdot 05$ )(Fig. 2). Quantification of total $\mathrm{p} 90^{\mathrm{RSK}}$ by Western blot revealed that the amount of kinase was not altered by the DEX treatment in epitrochlearis muscle (Fig. 2).

Stimulation of $\mathrm{p} 70^{\mathrm{S} 6 \mathrm{~K}}$ by insulin is characterized by an increase in its apparent molecular mass secondary to multiple phosphorylation sites of the kinase. Therefore we used this property (assessed by Western blot) as an indicator of hormone action on the kinase. DEX treatment did not modify the amount of $\mathrm{p} 70^{\mathrm{S} 6 \mathrm{~K}}$ protein recovered from epitrochlearis muscle (Fig. 3). The presence of insulin in the incubation medium greatly increased the phosphorylation of $\mathrm{p} 70^{\mathrm{S} 6 \mathrm{~K}}$ in pair-fed animals whereas no
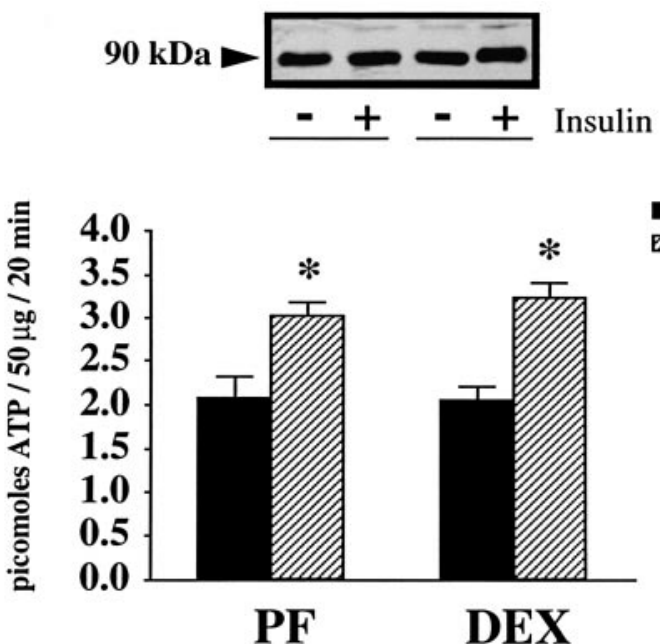

Figure 2 Activity of $\mathrm{p} 90^{\mathrm{RSK}}$ in rat skeletal muscle. Epitrochlearis muscles were preincubated for $30 \mathrm{~min}$ in Krebs/Henseleit buffer. Muscles were then incubated for $20 \mathrm{~min}$ in the presence or not of $30 \mathrm{nM}$ insulin. Muscles were homogenized in ice-cold extraction buffer and centrifuged at $10000 \mathrm{~g}$ for $10 \mathrm{~min}$ at $4{ }^{\circ} \mathrm{C}$. The activity of $\mathrm{p} 90^{\mathrm{RSK}}$ was assessed by an immune complex kinase assay. After a 20 min incubation at $30{ }^{\circ} \mathrm{C}$, the reaction mixture was spotted on to Whatman P-81 phosphocellulose filter paper squares and counted. Aliquots of tissue proteins were analysed by SDS/PAGE ( $7 \cdot 5 \%$ gel) under reducing conditions, transfered to a nylon membrane and exposed to a polyclonal antibody that specifically recognizes $p 90^{\text {RSK }}$. Data are means \pm S.E. for eight to ten individual muscles. *Significantly different from basal value $(P<0 \cdot 05)$.

modification of the electrophoretic motility was recorded in DEX-treated epitrochlearis muscle (Fig. 3). This observation suggests that the stimulation of $\mathrm{p} 70^{\text {S6K }}$ activity by insulin was impaired when rats were treated with steroids. The measurement of $\mathrm{p} 70^{\mathrm{S} 6 \mathrm{~K}}$ activity confirmed this observation as insulin greatly increased $\mathrm{p} 70^{\mathrm{S} 6 \mathrm{~K}}$ activity in pair-fed animals $(3 \cdot 44 \pm 0.55$ vs $0.71 \pm 0.18$ pmol ATP/ $100 \mu \mathrm{g}$ per $\mathrm{h}$ with and without insulin respectively; $P<0.05)$ whereas it had no significant stimulatory effect in DEX-treated rats $(0.78 \pm 0.12$ vs $0.56 \pm 0.12 \mathrm{pmol} \mathrm{ATP/}$ $100 \mu \mathrm{g}$ per $\mathrm{h}$ with and without insulin respectively) (Fig. 3). It is important to note that DEX did not modify the basal activity of $\mathrm{p} 70^{\mathrm{S} 6 \mathrm{~K}}$ in epitrochlearis muscle. This result suggests that the rapamycin pathway to which $\mathrm{p} 70^{\mathrm{S} 6 \mathrm{~K}}$ belongs may be in part responsible for the defect in insulin action on muscle protein synthesis in DEX-treated rats. In contrast with protein synthesis, food restriction greatly modifies both basal and insulin-stimulated $\mathrm{p} 70^{\mathrm{S} 6 \mathrm{~K}}$ in epitrochlearis muscle when compared with a control ad libitum group $(1 \cdot 296 \pm 0 \cdot 054$ vs $7 \cdot 010 \pm 0 \cdot 820 \mathrm{pmol}$ $\mathrm{ATP} / 100 \mu \mathrm{g}$ per $\mathrm{h}$ without and with insulin respectively). Thus, in order to assess the effect of DEX alone on the intracellular pathways involved in the stimulation of muscle protein synthesis by insulin, it is essential to compare the DEX group with a pair-fed group. 


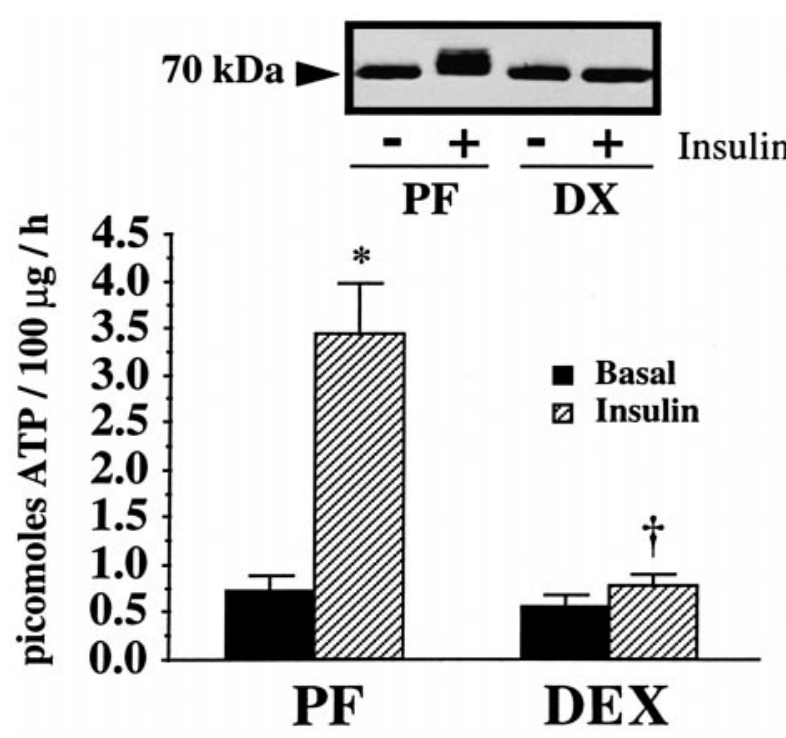

Figure 3 Activity of $\mathrm{p} 70^{\mathrm{S} 6 \mathrm{~K}}$ in rat skeletal muscle. Epitrochlearis muscles were preincubated as described in Fig. 2. The activity of p $70^{\text {S6K }}$ was assessed by an immune complex kinase assay. After a 60 min incubation at $30^{\circ} \mathrm{C}$, the phosphorylation reaction was stopped with unlabelled ATP. The reaction mixture was spotted on to Whatman P-81 phosphocellulose filter paper squares and counted in a $\beta$-scintillation counter. Aliquots of tissue supernatant ( $20 \mu$ g protein) were analysed by SDS/PAGE $(7 \cdot 5 \%$ polyacrylamide gel) under reducing conditions. Proteins were then transfered to a nylon membrane and exposed to a polyclonal antibody that specifically recognizes $\mathrm{p} 70^{\mathrm{S} 6 \mathrm{~K}}$. Data are means \pm S.E. for eight to ten individual muscles. *Significantly different from basal value $(P<0 \cdot 05)$; $†$ significantly different from the pair-fed value $(P<0 \cdot 05)$.

\section{Effect of rapamycin on insulin-stimulated protein synthesis}

The effect of rapamycin was assessed in an additional experiment in which the decrease in basal muscle protein synthesis and the defective action of insulin on muscle protein synthesis $(-39 \cdot 9 \%)$ was similar to the previous study (Fig. 4). Addition of rapamycin to the incubation medium did not modify basal protein synthesis in epitrochlearis muscle from pair-fed animals $(0 \cdot 241 \pm 0 \cdot 013$ vs $0.233 \pm 0.019 \mathrm{nmol}$ phenylalanine $/ \mathrm{mg}$ protein per 90 min without and with inhibitor respectively). Insulin increased protein synthesis but in the presence of rapamycin its effect was significantly reduced, by $0.071 \pm 0.004 \mathrm{nmol}$ phenylalanine $/ \mathrm{mg}$ protein per $90 \mathrm{~min}(0 \cdot 459 \pm 0.020$ vs $0.388 \pm 0 \cdot 015 \mathrm{nmol}$ phenylalanine/mg protein per 90 min respectively) (Fig. 4). Thus insulin partially stimulated muscle protein synthesis through a rapamycin-dependent pathway.

As observed with pair-fed animals, the addition of rapamycin did not modify basal protein but partially inhibited the insulin-stimulated protein synthesis in DEXtreated rats. This inhibition was similar to that recorded in pair-fed animals: 0.069 $\pm 0.002 \mathrm{nmol}$ phenylalanine $/ \mathrm{mg}$ protein per $90 \mathrm{~min}$ (from $0.293 \pm 0.019$ to $0.224 \pm$ $0 \cdot 015 \mathrm{nmol}$ phenylalanine/mg protein per $90 \mathrm{~min}$ with

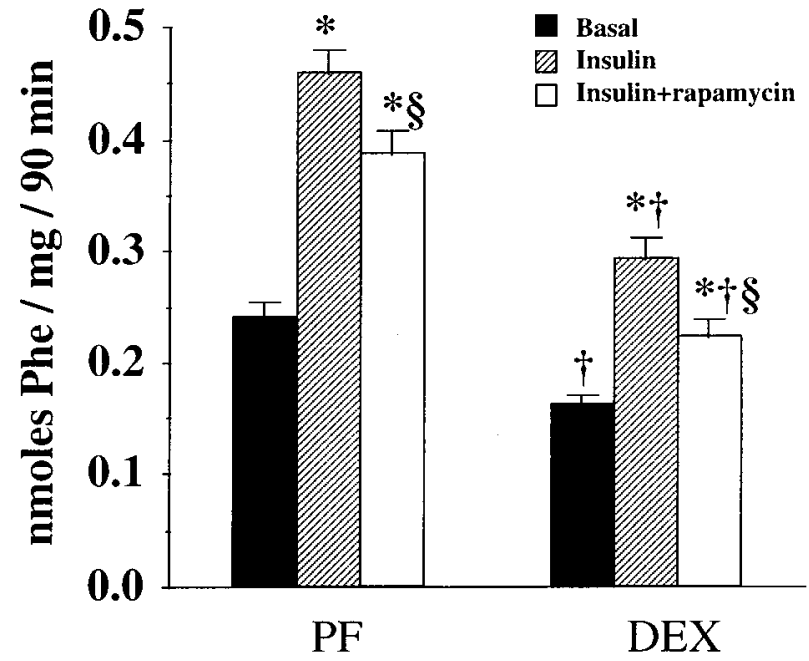

Figure 4 Effect of rapamycin on muscle protein synthesis. Epitrochlearis muscles from pair-fed (PF) and DEX-treated (DEX) rats were preincubated for $30 \mathrm{~min}$ in Krebs/Henseleit buffer supplemented with $5 \mathrm{mM}$ Hepes, $5 \mathrm{mM}$ glucose, $0 \cdot 17 \mathrm{mM}$ leucine, $0 \cdot 2 \mathrm{mM}$ valine, $0 \cdot 1 \mathrm{mM}$ isoleucine and $0 \cdot 1 \% \mathrm{BSA}$ and saturated with $95 \% \mathrm{O}_{2} / 5 \% \mathrm{CO}_{2}$ gas mixture in the presence or absence of $200 \mathrm{nM}$ rapamycin. Muscles were then transfered to fresh medium of the same composition supplemented with $0.5 \mathrm{mM} \mathrm{L-}\left[{ }^{14} \mathrm{C}\right]$ phenylalanine $(0 \cdot 15 \mu \mathrm{Ci} / \mathrm{ml})$ with or without $30 \mathrm{nM}$ insulin and incubated for an additional 90 min period. Muscles were blotted and homogenized in $10 \%$ TCA. The resultant pellet was solubilized in $1 \mathrm{M} \mathrm{NaOH}$ at $37{ }^{\circ} \mathrm{C}$ for determination of muscle protein content and radioactivity incorporated into muscle proteins. Protein synthesis was expressed as nmol phenylalanine incorporated/mg protein per $90 \mathrm{~min}$. Data are means \pm S.E. for eight to twelve individual muscles. * Significantly different from basal value $(P<0.05)$; $†$ significantly different from the pair-fed value $(P<0 \cdot 05)$; §significantly different from the corresponding value without rapamycin $(P<0 \cdot 05)$.

and without rapamycin respectively) (Fig. 4). This result shows that the insulin effect that is dependent on the rapamycin-sensitive pathway is not significantly altered in response to DEX and thus not responsible for the resistance observed.

\section{Discussion}

Glucocorticoids have direct effects on muscle protein turnover by either inhibiting protein synthesis (Tomas et al. 1979, Rannels \& Jefferson 1980, McGrath \& Goldspink 1982, Odedra et al. 1983, Kayali et al. 1987) or increasing proteolysis (Tomas et al. 1979, McGrath \& Goldspink 1982, Kayali et al. 1987). However, in vivo, they also act through their interaction with insulin. Accordingly, our study in rat epitrochlearis muscle showed that DEX significantly decreased basal muscle protein synthesis but also strongly depressed its stimulation by insulin. The effect of insulin on muscle protein metabolism in vivo is still an open question. Most of the experiments 
demonstrated that infusion of exogenous insulin does not increase muscle protein synthesis except in young fasted growing rats (Garlick \& Grant 1988, Mosoni et al. 1993). Thus it has been postulated that physiological concentrations of insulin already maximally stimulate protein synthesis in vivo. This was confirmed by the experiment of Sinaud et al. (1999) which demonstrated, in standard postprandial rats, that only a specific decrease in insulinaemia produced by diazoxide was able to show the role of insulin in the stimulation of muscle protein synthesis in vivo. The in vitro stimulation of protein synthesis by insulin in epitrochlearis muscle occurred in the range zero to physiological insulin concentration and thus confirms the previous hypothesis (Dardevet et al. 1994, Vary et al. 1998). In our experiment we used a dose of insulin that stimulated protein synthesis maximally (as in vivo) and we postulate that we were reproducing insulin stimulation that occurs in vivo. As physiological insulin levels already maximally stimulate muscle protein synthesis in vivo, the difference in insulin-stimulated protein synthesis that we observed in vitro should also be found in vivo. The results of both Odedra et al. (1983) and Southorn et al. (1990) agree with this. They demonstrated that the responsiveness of muscle protein synthesis to insulin was altered when rats were treated with steroids and that insulin infusion in vivo did not counteract the decrease in muscle protein synthesis.

Cellular responses to insulin involve interaction of the hormone with its receptor and subsequent activation of intracellular signalling pathways. It is now established that phosphorylation/dephosphorylation reactions play a major role in the control of protein synthesis by insulin. The involvement of PI3 kinase as a mediator of insulin action on muscle protein synthesis has been demonstrated in studies using a specific inhibitor of the kinase (Dardevet et al. 1996, Thompson \& Palmer 1998). However, PI3 kinase represents a general mechanism in insulin signalling; for example, several studies have shown that this kinase is also important in the regulation of glucose uptake (Okada et al. 1994, Cheatham et al. 1994, Yeh et al. 1995, Dardevet et al. 1996). The downstream events linked to PI3 kinase remain poorly defined but in several cell lines (Cheatham et al. 1994, Cross et al. 1994, Welsh et al. 1994, Chung et al. 1994) as well as in rat skeletal muscle (Dardevet et al. 1996), PI3 kinase activation was found to be required for insulin stimulation of $\mathrm{p} 70^{\mathrm{S} 6 \mathrm{~K}}$. Interestingly, using rapamycin, we previously showed that $\mathrm{p} 70^{\mathrm{S} 6 \mathrm{~K}}$ (a rapamycin-sensitive kinase) may be partially involved in the signalling pathway linking the insulin receptor to the protein synthesis machinery in rat epitrochlearis muscle, as in the presence of the inhibitor, insulin stimulation of protein synthesis was decreased by 25\% (Dardevet et al. 1996). In the present study, DEX treatment totally abolished the stimulation of $\mathrm{p} 70^{\mathrm{S} 6 \mathrm{~K}}$ by insulin in rat epitrochlearis muscle without decreasing the enzyme content. Therefore such a modification could explain the insulin resistance of the muscle protein synthesis in DEX-treated rats. In order to verify whether such an alteration was indeed responsible for the glucocorticoid-induced insulin resistance of protein synthesis, we compared the effect of rapamycin on insulin-stimulated protein synthesis between pair-fed and DEX-treated rats. Surprisingly, the addition of rapamycin decreased the effect of insulin to the same extent in both groups of rats suggesting that the rapamycin-sensitive pathway was not involved in the insulin resistance observed in spite of total blockage of the stimulation of $\mathrm{p} 70^{\mathrm{S} 6 \mathrm{~K}}$ by insulin. However, DEX-induced modification of the insulin-stimulated $\mathrm{p} 70^{\mathrm{S} 6 \mathrm{~K}}$ activity may explain the alteration in other metabolic effects of insulin in skeletal muscle. Indeed DEX treatment decreased the action of insulin on glucose transport (Weinstein et al. 1995) or glycogen synthesis (Leighton et al. 1987) in which the involvement of a rapamycin-sensitive mechanism (including elements of the $\mathrm{p} 70^{\mathrm{S} 6 \mathrm{~K}}$ signalling pathway) has been demonstrated (Azpiazu et al. 1996). Furthermore, insulin activates nuclear $\mathrm{p} 70^{\mathrm{S} 6 \mathrm{~K}}$ (Kim \& Kahn 1997) which has been shown to regulate the GLUT-1 and hexokinase II gene expression (Osawa et al. 1996, Taha et al. 1995). Thus, by inhibiting the $\mathrm{p} 70^{\mathrm{S} 6 \mathrm{~K}}$ activation by insulin, DEX may indirectly modify glucose metabolism but not protein synthesis.

Although rapamycin causes a deactivation of $\mathrm{p} 70^{\mathrm{S} 6 \mathrm{~K}}$, the direct target of this inhibitor is in fact the protein known as mTOR (mammalian target of rapamycin). The role of $\mathrm{mTOR}$ as the rapamycin target responsible for inhibition of $\mathrm{p} 70^{\mathrm{S} 6 \mathrm{~K}}$ was demonstrated by Brown et al. (1995) who showed that mutant TORs, which lack the ability to bind rapamycin, prevent the inhibition of $\mathrm{p} 70^{\mathrm{S} 6 \mathrm{~K}}$ by the drug. However, recent studies (Hara et al. 1997, Von Manteuffel et al. 1997) demonstrated that rapamycinresistant mutants of $\mathrm{p} 70^{\mathrm{S} 6 \mathrm{~K}}$ are not able to prevent the rapamycin-dependent dephosphorylation of eukariotic initiation factor 4E binding protein 1 (eIF4E-BP1), a target of insulin in the regulation of protein synthesis. Thus, even if mTOR is an upstream regulator of the $\mathrm{p} 70^{\mathrm{S} 6 \mathrm{~K}}$, other signalling pathways arise directly from mTOR and act independently of the $\mathrm{p} 70^{\mathrm{S} 6 \mathrm{~K}}$. Our experiment is consistent with this observation, as we showed in DEX-treated rats that rapamycin was still able to inhibit the stimulation of muscle protein synthesis by insulin in the absence of stimulation of $\mathrm{p} 70^{\mathrm{S} 6 \mathrm{~K}}$. As the lack of stimulation of $\mathrm{p} 70^{\mathrm{S} 6 \mathrm{~K}}$ by insulin in DEX-treated animals did not modify the rapamycin-associated decrease in protein synthesis, the involvement of $\mathrm{p} 70^{\mathrm{S} 6 \mathrm{~K}}$ in the regulation of muscle protein synthesis by insulin was questionable. Furthermore, as food restriction altered the stimulation of $\mathrm{p} 70^{\mathrm{S} 6 \mathrm{~K}}$ by insulin without having any effect on muscle protein synthesis, this observation supports our hypothesis that this kinase may not be directly involved in the regulation of muscle protein synthesis by insulin.

Insulin activates multiple cellular protein kinases (Myers \& White 1993). These include MAP kinases which are 
part of a signal-transduction pathway that is distinct from the rapamycin-sensitive pathway. Indeed, it has been shown that rapamycin does not block the activation of MAP kinase by insulin or the downstream kinase $\mathrm{p} 90^{\mathrm{RSK}}$ (Chung et al. 1992, Price et al. 1992, Fingar et al. 1993). Furthermore, because PI3 kinase activation was required for insulin stimulation of muscle protein synthesis (Dardevet et al. 1996, Palmer et al. 1997), and because wortmanin (inhibitor of PI3 kinase) has been shown to block the activation of MAP kinase by insulin in L6 myocytes (Cross et al. 1994) and CHO cells (Welsh et al. 1994), the role of this pathway in the DEX-induced insulin resistance of muscle protein synthesis was assessed in our model. Addition of the MAP kinase (MEK) inhibitor did not modify the stimulatory effect of insulin on muscle protein synthesis, suggesting that the MAP kinase pathway and its downstream elements were not involved in the regulation of the translation machinery. Our observations are in agreement with the study of Azpiazu et al. (1996) who concluded that the MAP kinase pathway was not necessary for insulin action on muscle protein synthesis in rat diaphragm. In consequence, the resistance of muscle protein synthesis to insulin in DEX-treated rats could not originate from a defect in this pathway. Furthermore, we showed that the stimulation by insulin of a downstream kinase of the MAP kinase pathway ( $\mathrm{p} 90^{\mathrm{RSK}}$ ) was not alterated by DEX treatment. However, the role of $\mathrm{p} 90^{\mathrm{RSK}}$ in the regulation of muscle protein synthesis has been proposed because it activates the glycogen synthase kinase 3 which is known to activate eIF2B (eukaryotic initiation factor 2B) in vitro (Welsh \& Proud 1993). The latter is a target of insulin in its regulation of the formation of the $43 \mathrm{~S}$ preinitiation complex (Kimball et al. 1994). However, DEX-induced insulin resistance of muscle protein synthesis was also independent of $\mathrm{p} 90^{\mathrm{RSK}}$ as treated animals did not show any alteration in the stimulation of this kinase by insulin. Further studies are nevertheless necessary to confirm whether or not $\mathrm{p} 90^{\mathrm{RSK}}$ represents an insulinstimulated kinase leading to stimulation of muscle protein synthesis.

Insulin modulates protein synthesis by enhancing initiation of translation of mRNA (Kimball et al. 1994). The rate-limiting step for translation is the initiation phase which involves recognition of capped mRNA and binding to the 40S ribosome (Altmann \& Trachsel 1993, Rhoads 1993, Sonenberg 1994). These processes require the participation of the initiation factor eIF4F, a complex composed of eIF4E (the cap binding protein), eIF4G and eIF4A (RNA helicase). eIF4E is the least abundant of the initiation factors and thus plays a critical regulatory role in protein synthesis. Modulation of its concentration by gene transfection leads to parallel modification of protein synthesis (Rhoads 1993, Sonenberg 1994). eIF4E activity is modulated by a protein known as 4E-BP-1 (also termed PHAS-I) which specifically binds to eIF4E and decreases translation (Lin et al. 1994, Pause et al. 1994).
Phosphorylation of PHAS-I in response to insulin resulted from a dissociation of the PHAS-I-eIF4E complex and thus increased free eIF4E for the formation of the complex eIF4F (Lin et al. 1994, 1995, Graves et al. 1995). To our knowledge, the effect of steroids on the insulin regulation of the complex PHAS-I-eIF4E has not been studied but we hypothesize that such a mechanism may occur in the generation of the insulin resistance of muscle protein synthesis in our model. Indeed, such a mechanism has been recently demonstrated in diabetes type I, another well-characterized insulin-resistant state. Interestingly, even if PHAS-I represents a substrate of MAP kinase in vitro (Haystead et al. 1994), several studies have shown that insulin-stimulated phosphorylation of the PHAS-IeIF4E was independent of the MAP kinase pathway in 3T3-L1 adipocytes (Lin et al. 1995) or rat diaphragm (Azpiazu et al. 1996) and was only partially blocked by rapamycin (Azpiazu et al. 1996). Further work will be required to demonstrate the contribution of such a mechanism in the generation of the DEX-induced insulin resistance of protein synthesis in rat epitrochlearis muscle.

In conclusion, our experiments show that glucocorticoid-induced insulin resistance of muscle protein synthesis is independent of the rapamycin-sensitive pathway despite a total inhibition of $\mathrm{p} 70^{\mathrm{S} 6 \mathrm{~K}}$ activation by insulin. In addition, our results on the $\mathrm{p} 90^{\mathrm{RSK}}$ and MAP kinases show that they also were not responsible for the insulin resistance observed. Investigations are needed to determined which intracellular kinases or factors are involved. From previous (Dardevet et al. 1996) and the present results, it was found that that these kinases are dependent on PI3 kinase but independent of rapamycin and MAP kinase. Protein kinase B (PKB) may be a good candidate because its activation by insulin was blocked by LY294002 (inhibitor of the PI3 kinase) and unaffected by rapamycin and PD98059 (inhibitor of MAP kinase pathways; see Cohen et al. (1997) for a review). Furthermore, this kinase has been linked to the glycogen synthase kinase 3 in skeletal muscle (Cohen et al. 1997). Whether or not $\mathrm{PKB}$ is responsible for the insulin resistance of protein synthesis in DEX-treated rats remains to be determined.

\section{References}

Altmann M \& Trachsel H 1993 Regulation of translation initiation and modulation of cellular physiology. Trends in Biochemical Science 18 429-432.

Amatruda JM, Livingston JN \& Lockwood DH 1985 Cellular mechanisms in selected states of insulin resistance: human obesity, glucocorticoid excess, and chronic renal failure. Diabetes Metabolism Reviews 1 293-317.

Azpiazu I, Saltiel AR, Depaoliroach AA \& Lawrence JC 1996 Regulation of both glycogen synthase and PHAS-I by insulin in rat skeletal muscle involves mitogenactivated protein kinaseindependent and rapamycin-sensitive pathways. Journal of Biological Chemistry 271 5033-5039. 
Block NE \& Buse MG 1989 Effects of hypercotisolemia and diabetes on skeletal muscle insulin receptor function in vitro and in vivo. American Journal of Physiology 256 E39-E48.

Bondy PK 1985 Disorders of the adrenal cortex. In Williams' Textbook of Endocrinology, edn 7, pp 816-890. Eds JD Wilson \& DW Foster. Philadelphia: Saunders.

Brown EJ, Beal PA, Keith CT, Chen J, Shin TB \& Schreiber SL 1995 Control of p70 S6 kinase by kinase activity of FRAP in vivo. Nature 377 441-446.

Cheatham B, Vlahos CJ, Cheatham L, Wang L, Blenis J \& Kahn CR 1994 Phosphatidylinositol 3-kinase activation is required for insulin stimulation of pp70 S6 kinase, DNA synthesis, and glucose transporter translocation. Molecular and Cellular Biology 14 4902-4911.

Chung J, Kuo CJ, Crabtree GR \& Blenis J 1992 Rapamycin-FKBP specifically blocks growth dependent activation of and signaling by the $70 \mathrm{kd}$ S6 protein kinases. Cell 69 1227-1236.

Chung JK, Grammer TC, Lemon KP, Kazlauskas A \& Blenis J 1994 PDGF- and insulin-dependent p70(S6k) activation mediated by phosphatidylinositol-3-OH kinase. Nature 370 71-75.

Cohen P, Alessi DR \& Cross DAE 1997 PDK1, one of the missing links in insulin signal transduction? FEBS Letters 410 3-10.

Cross DAE, Alessi DR, Vandenheede JR, McDowell HE, Hundal HS, Cohen P 1994 The inhibition of glycogen synthase kinase- 3 by insulin or insulin-like growth factor 1 in the rat skeletal muscle cell line L6 is blocked by wortmannin, but not by rapamycin: evidence that wortmannin blocks activation of the mitogen-activated protein kinase pathway in L6 cells between ras and raf. Biochemical Journal 303 21-26.

Dardevet D, Sornet C, Attaix D, Baracos VE \& Grizard J 1994 Insulin-Like Growth Factor-1 and insulin resistance in skeletal muscles of adult and old rats. Endocrinology 134 1475-1484.

Dardevet D, Sornet C, Vary T \& Grizard J 1996 Phosphatidylinositol 3-kinase and p70 S6 kinase participate in the regulation of protein turnover in skeletal muscle by insulin-like growth factor I. Endocrinology 137 4087-4094.

Dardevet D, Sornet C, Savary I, Debras E, Patureau Mirand P \& Grizard J 1998 Glucocorticoid effects on insulin- and IGF-Iregulated muscle protein metabolism during aging. Journal of Endocrinology 156 83-89.

Denton RM \& Tavaré JM 1995 Does mitogen-activated-protein kinase have a role in insulin action? The cases for and against. European Journal of Biochemistry 227 597-611.

Dujovne LA \& Azarnoff DL 1975 Clinical complications of corticosteroid therapy: a review. In Steroid Therapy, pp 27-47. Ed DL Azarnoff. Philadelphia: Saunders.

Fingar DC, Hausdorff SF, Blenis J \& Birnbaum MJ 1993 Dissociation of p70 ribosomal protein $\mathrm{S} 6$ kinase from insulin-stimulated glucose transport in 3T3-L1 adipocytes. Journal of Biological Chemistry 268 3005-3008.

Garlick PJ \& Grant I 1988 Amino acid infusion increases the sensitivity of muscle protein synthesis in vivo to insulin: effect of branch-chain amino acids. Biochemical Journal 254 579-584.

Giorgino F, Almahfouz A, Goodyear LJ \& Smith RJ 1993 Glucocorticoid regulation of insulin receptor and substrate IRS-1 tyrosine phosphorylation in rat skeletal muscle in vivo. Journal of Clinical Investigation 91 2020-2030.

Graves LM, Bornfeldt KE, Argast GM, Krebs EG, Kong XM, Lin TA \& Lawrence JC 1995 cAMP- and rapamycin-sensitive regulation of the association of eukaryotic initiation factor $4 \mathrm{E}$ and the translational regulator PHAS-I in aortic smooth muscle cells. Proceedings of the National Academy of Sciences of the USA 92 7222-7226.

Hara K, Yonezawa K, Kozlowski MT, Sugimoto T, Andrabi K, Weng QP, Kasuga M, Nishimoto I \& Avruch J 1997 Regulation of eIF-4E BP1 phosphorylation by mTOR. Journal of Biological Chemistry 272 26457-26463.

Haystead TAJ, Haystead CMM, Hu CB, Lin TA \& Lawrence JC Jr 1994 Phosphorylation of PHAS-I by mitogen-activated protein
(MAP) kinase identification of a site phosphorylated by MAP kinase in vitro and in response to insulin in rat adipocytes. Journal of Biological Chemistry 269 23185-23191.

Kayali AG, Young VR \& Goodman MN 1987 Sensitivity of myofibrillar proteins to glucocorticoid-induced muscle proteolysis. American Journal of Physiology 252 E621-E626.

Kim SJ \& Kahn CR 1997 Insulin stimulates p70 S6 kinase in the nucleus of cells. Biochemical and Biophysical Research Communications 234 681-685.

Kimball SR, Vary TC \& Jefferson LS 1994 Regulation of protein synthesis by insulin. Annual Review of Physiology 56 321-348.

Legaspi A, Albert JD, Calvano SE, Brennan MF \& Lowry SF 1985 Proteolysis of skeletal muscle in response to acute elevation of plasma cortisol in man. Surgical Forum 36 16-18.

Leighton B, Challiss RAJ, Lozeman PJ \& Newsholme EA 1987 Effects of dexamethasone treatment on insulin-stimulated rates of glycolysis and glycogen synthesis in isolated incubated skeletal muscles of the rat. Biochemical Journal 246 551-554.

Lin TA, Kong XM, Haystead TAJ, Pause A, Belsham G, Sonenberg N \& Lawrence JC Jr 1994 PHAS-1 as a link between mitogenactivated protein kinase and translation initiation. Science $\mathbf{2 6 6}$ 653-656.

Lin TA, Kong XM, Saltiel AR, Blackshear PJ \& Lawrence JC 1995 Control of PHAS-I by insulin in 3T3-L1 adipocytes synthesis, degradation, and phosphorylation by a rapamycin-sensitive and mitogen-activated protein kinase-independent pathway. Journal of Biological Chemistry 270 18531-18538.

Louard RJ, Bhushan R, Gelfand RA, Barrett EJ \& Sherwin RS 1994 Glucocorticoids antagonize insulin's antiproteolytic action on skeletal muscle in humans. Journal of Clinical Endocrinology and Metabolism 79 278-284.

McGrath JA \& Goldspink DF 1982 Glucocorticoid action on protein synthesis and protein breakdown in isolated skeletal muscles. Biochemical Journal 206 641-645.

Mosoni L, Patureau Mirand P, Houlier ML \& Arnal M 1993 Agerelated changes in protein synthesis measured in vivo in rat liver and gastrocnemius muscle. Mechanisms of Ageing and Development $\mathbf{6 8}$ 209-220.

Myers MG \& White MF 1993 The new elements of insulin signaling-insulin receptor substrate-1 and proteins with $\mathrm{SH} 2$ domains. Diabetes 42 643-650.

Odedra BR, Bates PC \& Millward DJ 1983 Time course of the effect of catabolic doses of corticosterone on protein turnover in rat skeletal muscle and liver. Biochemical Journal 214 617-627.

Okada T, Kawano Y, Sakakibara T, Hazeki O \& Ui M 1994 Essential role of phosphatidylinositol 3-kinase in insulin-induced glucose transport and antilipolysis in rat adipocytes: studies with a selective inhibitor wortmannin. Journal of Biological Chemistry 269 3568-3573.

Osawa H, Sutherland C, Robey RB, Printz RL \& Granner DK 1996 Analysis of the signaling pathway involved in the regulation of hexokinase II gene transcription by insulin. Journal of Biological Chemistry 271 16690-16694.

Palmer RM, Thompson MG, Knott RM, Campbell GP, Thom A \& Morrison KS 1997 Insulin and insulin-like growth factor-I responsiveness and signalling mechanisms in $\mathrm{C} 2 \mathrm{C} 12$ satellite cells: effect of differentiation and fusion. Biochimica et Biophysica Acta 1355 $167-176$

Pause A, Belsham GJ, Gingras AC, Donzé O, Lin TA, Lawrence JC \& Sonenberg N 1994 Insulin-dependent stimulation of protein synthesis by phosphorylation of a regulator of $5^{\prime}$-cap function. Nature 371 762-767.

Price DJ, Russell Grove J, Calvo V, Avruch J \& Bierer BE 1992 Rapamycin-induced inhibition of the 70-kilodalton S6 protein kinase. Science 257 973-976.

Rannels SR \& Jefferson LS 1980 Effects of glucocorticoids on muscle protein turnover in perfused rat hemicorpus. American Journal of Physiology 238 E564-E572. 
Rhoads RE 1993 Regulation of eukaryotic protein synthesis by initiation factors. Journal of Biological Chemistry 268 017-302.

Saad MJA, Folli F, Kahn JA \& Kahn CR 1993 Modulation of insulin receptor, insulin receptor substrate-1, and phosphatidylinositol 3-kinase in liver and muscle of dexamethasone-treated rats. Journal of Clinical Investigation 92 2065-2072.

Sinaud S, Balage M, Bayle G, Dardevet D, Vary TC, Kimball SR, Jefferson LS \& Grizard J 1999 Diazoxide-induced insulin deficiency greatly reduced muscle protein synthesis in rats. Involvement of eIF-4E. American Journal of Physiology 276 E50-E61.

Sonenberg N 1994 Regulation of translation and cell growth by eIF-4E. Biochimie 76 839-846.

Southorn BG, Palmer RM \& Garlick PJ 1990 Acute effects of corticosterone on tissue protein synthesis and insulin-sensitivity in rats in vivo. Biochemical Journal 272 187-191.

Taha C, Mitsumoto Y, Liu Z, Skolnik EY \& Klip A 1995 The insulin-dependent biosynthesis of GLUT1 and GLUT3 glucose transporters in L6 muscle cells is mediated by distinct pathwaysroles of p21(ras) and p70 S6 kinase. Journal of Biological Chemistry $27024678-24681$.

Tessitore L, Costelli P \& Baccino FM 1993 Humoral mediation for cachexia in tumour-bearing rats. British Journal of Cancer 67 15-23.

Thompson MG \& Palmer RM 1998 Signalling pathways regulating protein turnover in skeletal muscle. Cell Signal 10 1-11.

Tomas FM, Munro HN \& Young VR 1979 Effect of glucocorticoid administration on the rate of muscle protein breakdown in vivo in rats, as measured by urinary excretion of Ntau-methylhistidine. Biochemical Journal 178 139-146.

Vary TC, Dardevet D, Grizard J, Voisin L, Buffière C, Denis P, Breuillé D \& Obled C 1998 Differential regulation of skeletal muscle protein turnover by insulin and IGF-I after bacteremia. American Journal of Physiology 275 E584-E593.

Vaughan GM, Becker RA, Allen JP, Goodwin CV, Pruitt BA \& Mason AD 1982 Cortisol and corticotropin in burned patients. Journal of Trauma 22 263-273.

Von Manteuffel SR, Dennis PB, Pullen N, Gingras AC, Sonenberg N \& Thomas G 1997 The insulin-induced signalling pathway leading to $\mathrm{S} 6$ and initiation factor 4E binding protein 1 phosphorylation bifurcates at a rapamycin-sensitive point immediately upstream of p70(s6k). Molecular and Cellular Biology 17 5426-5436.

Weinstein SP, Paquin T, Pritsker A \& Haber RS 1995 Glucocorticoid-induced insulin resistance: dexamethasone inhibits the activation of glucose transport in rat skeletal muscle by both insulin and non-insulin-related stimuli. Diabetes 44 441-445.

Welsh GI \& Proud CG 1993 Glycogen synthetase kinase-3 is rapidly inactivated in response to insulin and phosphorylates eukaryotic initiation factor elF-2B. Biochemical Journal 294 625-629.

Welsh GI, Foulstone EJ, Young SW, Tavare JM \& Proud CG 1994 Wortmannin inhibits the effects of insulin and serum on the activities of glycogen synthase kinase- 3 and mitogen-activated protein kinase. Biochemical Journal 303 15-20.

Yeh JI, Gulve EA, Rameh L \& Birnbaum MJ 1995 The effects of wortmannin on rat skeletal muscle dissociation of signaling pathways for insulin- and contraction-activated hexose transport. Journal of Biological Chemistry 270 2107-2111.

Received 3 November 1998

Accepted 11 February 1999 